\title{
Bibliotherapy Strategy: Experimental Study To Reduce Hospitalization Stress In Pre-School Children
}

\author{
Kili Astarani*, Selvia David Richard \\ STIKES RS. Baptis Kediri, Indonesia \\ *astaranikili79@gmail.com
}

\begin{abstract}
Children who experience hospitalization will try to adapt to new and foreign environments that can lead to hospitalization stress. The impact of hospitalization stress on children is to make children refuse the treatment and medication given, so that it affects the length of days treated, aggravates the child's condition, and can even cause death in children. One of the nursing care for children is using therapeutic communication with bibliotherapy. Bibliotherapy can help children express their feelings and concerns through reading activities. This study aims to prove the effect of bibliotherapy on hospitalization stress in preschool children who are treated in the Karunia Room of Kediri Baptist Hospital.

The research design used the Pre-Experiment Design with a one-group pre-post test design. The population, preschool-aged children who experience hospitalization stress in the Karunia Room of Kediri Baptist Hospital. The sample is 15 respondents who were selected by Quota Sampling. The research variable was Bibliotherapy. The data collection process was carried out using a questionnaire. Data analysis using Paired Samples Test.

The results of the research before doing bibliotherapy, stress hospitalization of preschool children were severe as 9 respondents $(60.0 \%)$, mild as many as 4 respondents $(26.7 \%)$, and moderate as many as 2 respondents $(13.3 \%)$. The average change in stress hospitalization before and after bibliotherapy was 7.67 with a p-value of 0.000 .

Bibliotherapy is effective in reducing hospitalization stress in preschool children in the Karunia Room of Kediri Baptist Hospital.
\end{abstract}

Keywords : Bibliotherapy, Hospitalization Stress, Preschool Children

Received August 8, 2020; Revised August 28, 2020; Accepted September 19, 2020 


\section{STRADA Jurnal Ilmiah Kesehatan}

DOI: $10.30994 /$ sjik.v9i2.412

ISSN: 2252-3847 (print); 2614-350X (online)

Vol.9 No.2 November 2020 Page.917-925

\section{BACKGROUND}

Sickness and hospitalization are major crises in children, this is because children try to adapt to a new and foreign environment, namely the hospital so that these conditions become stressors for both children and parents and families, changing this condition is a big problem that raises fear, anxiety for children which can cause physiological and psychological changes in children if the child is unable to adapt to these changes (Saputro, 2017). The cause of children experiencing a crisis in the hospital is because children experience changes, both in terms of their health status and their environment from their daily habits, children have a number of limitations in coping mechanisms to deal with pressing events (Susilaningrum, 2013).

The results of a preliminary study conducted in the Karunia Room of Kediri Baptist Hospital were obtained from 15 respondents, 12 respondents (80\%) children felt ashamed or afraid when they met other people in the hospital, 11 respondents $(73.3 \%)$ children were afraid of being hospitalized, 13 respondents $(86.6 \%)$ asked children to wait or not to be separated from their parents.

The impact of children's hospitalization will react to separation with regression and refuse to cooperate, children will feel lost control because they experience loss of their own strength, children are afraid of body injuries and pain, lead to fear of mutilation and painful procedures, children will interpret hospitalization as punishment and separation from parents as a loss of affection (Andriana, 2011). According to Levi, 2006 in Astarani 2017, besides that, the stress experienced by children in the short term from anxiety and fear that are not immediately handled will make the child reject the treatment and treatment given, so that it affects the length of days treated, aggravates the child's condition and even can cause death in children.

In children who are hospitalized because of the many problems they experience, both related to their illness, and because of their fear and anxiety about the situation and action procedures, the child becomes quieter or does not communicate (Wong, 2009). This situation if left unchecked can have an adverse effect on growth and development in addition to the healing process of the disease. Nursing care for children who experience hospitalization stress by using bibliotherapy with the use of books in the context of a therapeutic and supportive process. This bibliotherapy helps children express their feelings and concerns through reading activities, this method can provide opportunities for children to explore an event that is similar to their situation but is slightly different to allow them to limit it from the story and remain in control (Muhith, 2018). Bibliotherapy is also a method that can help children understand trauma, learn to understand new problems and engage the problem from a different perspective. On the other hand, by using bibliotherapy, children who experience certain diseases or disabilities can feel a certain satisfaction by reading biographies or stories of successful adjustment of people who have experienced the same suffering. Health, Pehrsson \& McMillen (in Apriliawati, 2011). Seeing the above phenomenon, the researcher wanted to examine the effect of bibliotherapy on hospitalization stress in preschool children in the Karunia Room of Kediri Baptist Hospital.

\section{METHODS}

The research design used the Pre Experiment Design with a one-group pre-post test design. Subjects were preschool-aged children who experienced hospitalization stress in the Karunia Room of Kediri Baptist Hospital, a total of 15 respondents who were selected by Quota Sampling. Collecting data from 18 May to 18 June 2020. The variable of this study 


\section{STRADA Jurnal Ilmiah Kesehatan}

DOI: $10.30994 /$ sjik.v9i2.412

ISSN: 2252-3847 (print); 2614-350X (online)

Vol.9 No.2 November 2020 Page.917-925

was Bibliotherapy. Measurement of stress hospitalization in children has been tested for validity and reliability using Cronbach Alfa with results $\alpha=0.919$. The data collection process was carried out by means of a questionnaire. Data analysis using Paired Samples Test.

\section{RESULT}

Table 1 General Data Characteristics of Respondents of Preschool Children in the Karunia Room of Kediri Baptist Hospital from 18 May - 18 June 2020 (n = 15)

\begin{tabular}{|c|c|c|}
\hline Characteristics & $\begin{array}{l}\text { Number of } \\
\text { Respondents }\end{array}$ & Percentage $(\%)$ \\
\hline \multicolumn{3}{|l|}{ Child Age (years) } \\
\hline $3-4$ & 9 & 60,0 \\
\hline $5-6$ & 6 & 40,0 \\
\hline Total & 15 & 100,00 \\
\hline \multicolumn{3}{|c|}{ Order of birth (sequence of children) } \\
\hline $1-2$ & 10 & 66,7 \\
\hline$>2$ & 5 & 33,3 \\
\hline Total & 15 & 100,00 \\
\hline \multicolumn{3}{|l|}{ Gender } \\
\hline Male & 8 & 53,3 \\
\hline Female & 7 & 46,7 \\
\hline Total & 15 & 100,00 \\
\hline \multicolumn{3}{|l|}{ Inpatient experience } \\
\hline Ever & 13 & 86,7 \\
\hline Never & 2 & 13,3 \\
\hline Total & 15 & 100,00 \\
\hline \multicolumn{3}{|l|}{ Number of Family Members } \\
\hline 1 person & 2 & 13,3 \\
\hline 2 persons & 3 & 20,2 \\
\hline$>2$ persons & 10 & 66,7 \\
\hline Total & 15 & 100,00 \\
\hline \multicolumn{3}{|l|}{ Number of Siblings } \\
\hline 1 person & 6 & 40,0 \\
\hline 2 persons & 5 & 33,3 \\
\hline$>2$ persons & 4 & 26,7 \\
\hline Total & 15 & 100,00 \\
\hline \multicolumn{3}{|l|}{ Father's Age (years) } \\
\hline $20-35$ & 8 & 53,3 \\
\hline $36-50$ & 6 & 40,0 \\
\hline $51-60$ & 1 & 6,7 \\
\hline Total & 15 & 100,00 \\
\hline Father's Occupation & & \\
\hline
\end{tabular}




\section{STRADA Jurnal Ilmiah Kesehatan}

DOI: $10.30994 /$ sjik.v9i2.412

\section{Characteristics}

\begin{tabular}{lcc} 
& Respondents & \\
\hline Work & 14 & 93,3 \\
\hline Doesn't work & 1 & $\mathbf{1 0 0 , 0 0}$ \\
\hline Total & $\mathbf{1 5}$ & \\
\hline Father's Education & 0 & 0 \\
\hline No School & 0 & 0 \\
\hline Primary school & 0 & 46,7 \\
\hline Junior High School & 7 & 53,3 \\
\hline High School & 8 & $\mathbf{1 0 0 , 0 0}$ \\
\hline Bachelor & $\mathbf{1 5}$ & 53,3 \\
\hline Total & & 40,0 \\
\hline Mother's age (years) & 8 & 6,7 \\
\hline $20-35$ & 6 & $\mathbf{1 0 0 , 0 0}$ \\
\hline $36-50$ & 1 & \\
\hline $51-60$ & $\mathbf{1 5}$ & 73,3 \\
\hline Total & & $\mathbf{1 0 0 , 0 0}$ \\
\hline Mother's Occupation & 11 & \\
\hline Work & 4 & 0 \\
\hline Doesn't work & $\mathbf{1 5}$ & 0 \\
\hline Total & & 0 \\
\hline Mother's Education & 0 & 53,3 \\
\hline No School & 0 & $\mathbf{1 0 0 , 0 0}$ \\
\hline Primary school & 0 & \\
\hline Junior High School & 8 & 7 \\
\hline High School & $\mathbf{1 5}$ & \\
\hline Bachelor & & \\
\hline Total & & \\
\hline & & \\
\hline & & \\
\hline
\end{tabular}

Based on Table 1, it was found that most pre-school children aged 3 - 4 years were 9 respondents $(60.0 \%)$. Most of the respondents were children $1-2$, as many as 10 people $(66.7 \%), 8$ respondents $(53.3 \%)$ male, 13 respondents $(86.7 \%)$ had experienced in the hospital. The majority of respondents lived in one house with more than 2 members as many as 10 respondents $(66.7 \%)$, had 1 sibling as many as 6 respondents $(40.0 \%)$, most of the respondents' fathers were $20-35$ years old as many as 8 people ( $53.3 \%$ ), the majority of respondents' fathers worked as many as 14 respondents $(93.3 \%)$, more than $50 \%$ of the final education level of the respondent's father's Bachelor degree was 8 people $(53.3 \%)$, more than $50 \%$ of the respondent's mother's age was 20-35 8 people $(53.3 \%)$ years, more than $50 \%$ of respondents' mothers work as many as 11 people (73.3\%), more than $50 \%$ of the mother's education level is high school level as many as 8 people $(53.3 \%)$

Frequency distribution of stress hospitalization in preschool-aged children in the Karunia Room of Kediri Baptist Hospital 


\section{STRADA Jurnal Ilmiah Kesehatan}

DOI: $10.30994 /$ sjik.v9i2.412

ISSN: 2252-3847 (print); 2614-350X (online)

Vol.9 No.2 November 2020 Page.917-925

Table 2 Frequency distribution of stress hospitalization in preschool aged children in theKarunia Room of Kediri Baptist Hospital from 18 May - 18 June 2020.

\begin{tabular}{|c|c|c|}
\hline Hospitalization Stress Rates & Number & Percentage $(\%)$ \\
\hline Mild & 4 & 26,7 \\
\hline Moderate & 2 & 13,3 \\
\hline Severe & 9 & 60,0 \\
\hline Total & 15 & 100,0 \\
\hline
\end{tabular}

Based on table 2, it is explained that more than $50 \%$ of respondents experienced severe hospitalization stress as 9 respondents $(60.0 \%)$, mild as many as 4 respondents (26.7\%), and moderate as many as 2 respondents $(13.3 \%)$.

Table 3 Statistical Test Results "Paired Samples Test" regarding the effect of Bibliotherapy on Hospitalization Stress in Preschool Age Children in the Karunia Room of Kediri Baptist Hospital $(n=15)$

\begin{tabular}{cccccc}
\hline Variable & $\Delta$ Mean & SD & t & df & $\begin{array}{c}\text { P Value } \\
\text { (Paired } \\
\text { samples test) }\end{array}$ \\
\hline $\begin{array}{c}\text { Changes in } \\
\text { hospitalization stress } \\
\text { before and after } \\
\text { bibliotherapy }\end{array}$ & 7,67 & 5,30 & 5,602 & 14 & 0,000 \\
\hline
\end{tabular}

Based on Table 3, it shows the average changes in stress hospitalization before and after bibliotherapy. Further analysis showed a significant change between the average hospitalization stress scores before and after bibliotherapy. In other words, bibliotherapy can significantly reduce hospitalization stress by 7.67 with a $p$-value of $0.000(p<0.05)$.

\section{DISCUSSION}

\section{Hospitalization Stress in Preschool Children at Kediri Baptist Hospital}

The level of hospitalization stress in preschool-aged children before bibliotherapy was carried out from 9 children $(60.0 \%)$ who experienced hospitalization stress in the severe category, 4 respondents $(26.7 \%)$ in the mild category, and 2 respondents $(13.3 \%)$ in the moderate category.

Hospitalization is a crisis that occurs in children when the child is sick and is hospitalized. This situation is caused because the child tries to adapt to a foreign or new environment, namely the hospital so that this condition becomes a stressor for both the child and parents and family (Wong, 2008) quoted in Astarani (2017). Hospitalization is a process for reasons of planning or an emergency that requires staying in the hospital to undergo therapy and treatment until returning home. According to Astarani (2017), when a child is in the hospital it can cause big problems, including fear, anxiety for the child. Children who are hospitalized are prone to crises because children experience changes, both in their health status and in their environment from their daily habits, children have 


\section{STRADA Jurnal Ilmiah Kesehatan}

DOI: $10.30994 /$ sjik.v9i2.412

ISSN: 2252-3847 (print); 2614-350X (online)

Vol.9 No.2 November 2020 Page.917-925

several limitations in coping mechanisms to overcome the problem of stressful events. The reaction of children in overcoming the crisis is influenced by the level of age development, previous experiences with illness and care, the available support systems, and coping skills in dealing with stress (Susilaningrum, 2013). During the hospitalization process, children can experience various events that indicate a very traumatic and stressful experience.

Preschool children are children aged 3 to 6 years, were at that age the child has not been able to accept and perceive new diseases and experiences that must be faced because they have to be admitted to the hospital, which in this case is referred to as hospitalization. Preschool-aged children who are treated in the Karunia room of Kediri Baptist Hospital have severe to moderate hospitalization stress. This happens because children are required to be admitted to the hospital due to a disease experienced and require children to be able to adapt to their new environment which can affect stressors for children and their parents and family. The severe stress experienced by preschool children while in the hospital is evidenced by the fact that children often fuss or cry while being treated in hospital, children also do not want to be left by their parents even for a while. Stress conditions in children who are hospitalized are the main crisis seen in children, this situation makes children have to adapt to new environments such as meeting nurses, doctors, and health workers who have not been known before. The state of moderate and severe stress experienced by children will affect the recovery process, children who are hospitalized for reasons of planning or emergency must undergo the treatment process until they recover and return home. Children will experience changes in both health status, environment, and daily habits such as playing with friends, family, or relatives. Hospitalization stress experienced by preschool children is one of the problems that must be resolved during the recovery process in the hospital. The reaction of children in dealing with problems can be influenced by several factors such as the level of age development. Age is associated with the development of a child's mindset in understanding hospitalization. Preschool children have not been able to accept and perceive new illnesses or experiences while being treated in the hospital. The younger the child's age, the stress level of hospitalization will be higher, the response that can be seen from the child looking scared when the health worker comes and the child asks to go home. Preschoolers who have been hospitalized before will have a lower level of anxiety than children who have no experience at all. The child's response will show sensitivity to the surrounding environment. The experience of having done treatment also makes the child connect previous events with current treatment, children who have unpleasant experiences while being treated in the hospital will make the child anxious and traumatized. Conversely, if the child has a good and pleasant experience while being treated in the hospital, the child will tend to be cooperative with a mild level of anxiety. Hospitalization as a support system provides opportunities for both children and parents for social acceptance, they will feel that the crisis experienced is not only felt by themselves, the child or parent can interact and share experiences experienced during the treatment process and can help parents in supporting their child's recovery. Preschoolaged children who have experience being hospitalized will have skills in dealing with problems that can affect the healing process until they return home.

\section{The influence of bibliotherapy on hospitalization stress in preschool children in the Karunia Room of the Kediri Baptist Hospital.}

Based on the results of the study, there was an effect of bibliotherapy with a reduction in the stress level of hospitalization in preschool children where $p=0.000$ so that 


\section{STRADA Jurnal Ilmiah Kesehatan}

DOI: $10.30994 /$ sjik.v9i2.412

ISSN: 2252-3847 (print); 2614-350X (online)

Vol.9 No.2 November 2020 Page.917-925

H1 had a significant effect before and after bibliotherapy with hospitalization stress in preschool children.

Nursing care for children experiencing hospitalization stress by using therapeutic communication, bibliotherapy therapeutic communication types, involving the use of books in the context of a therapeutic and supportive process. This bibliotherapy helps children express their feelings and concerns through reading activities, this way can allow children to explore an event that is similar to the situation but is slightly different to allow him to limit it from the story and stay in control the book is not threatening because children can at any time close the book or stop reading it. (Muhith. 2018). The term bibliotherapy comes from Greek, namely, the Bible means to book, and therapy is a psychological help effort, therefore bibliography can be defined as the use of books to help solve problems. The Webster dictionary (1985) is quoted in Suhron (2017). Defines bibliotherapy as a guideline for solving personal problems through reading.

The average reduction in hospitalization stress in pre-school children, before and after bibliotherapy was 7.67. Nursing intervention using bibliotherapy technique is one of the interventions proven to be effective in reducing stress in children experiencing hospitalization stress. Children experiencing severe to moderate hospitalization stress experienced a decrease after nursing intervention with therapeutic bibliotherapy communication. Before doing bibliotherapy, you feel unfamiliar with your environments, such as meeting a doctor, nurse, or other health workers. This makes children feel anxious and easy to experience stress hospitalization, using therapeutic communication techniques can reduce the level of anxiety in children. One of the therapeutic communications that can be done to reduce hospitalization stress in children is by using bibliotherapy therapeutic communication. Bibliotherapy is a method that can be done by using a storybook according to the child's situation. This therapy can help children to be more courageous to express their feelings and concerns through reading activities. This method is very helpful in providing opportunities for children to explore an event similar to their situation but the child is still in a controlled condition so that when the therapy is carried out the child does not feel bored, lazy and bored, this is done so that the child does not immediately end the story that is being done. Bibliotherapy in the Greek sense means book and therapy, which is one of the methods used to help children to deal with problems that occur in children, namely psychological problems, especially in children who are hospitalized and experience hospitalization stress. The book used in this research is a book entitled "My story: Hospital care". In this story the child can see an example of a child who is afraid to go to the doctor, by knowing an example from a storybook about the condition of a sick child, the child can understand about care for the sick and children can recognize medical tools such as those in storybooks. Bibliotherapy can help children overcome emotional turmoil related to life problems (in this case stress hospitalization) by reading stories related to their current condition. Hospice stories in bibliotherapy can be used as a springboard for discussion and possible self-crisis resolution through hands-on reading and supportive activities. Bibliotherapy interventions can be applied to children undergoing hospitalization, bibliotherapy interventions can be carried out by nurses and those closest to caring for children so that they are easy to implement for children. Bibliotherapy can be a choice of books for children who experience hospitalization stress. It is proven that children experiencing hospitalization stress have decreased. 


\section{STRADA Jurnal Ilmiah Kesehatan}

DOI: $10.30994 /$ sjik.v9i2.412

ISSN: 2252-3847 (print); 2614-350X (online)

Vol.9 No.2 November 2020 Page.917-925

\section{CONCLUSION}

Preschool children experienced hospitalization stress in the severe category when hospitalization was carried out, namely 9 children (60.0\%). Bibliotherapy affects reducing hospitalization stress in preschool children in the Karunia Room of Kediri Baptist Hospital.

Nursing care for preschool-aged children who experience hospitalization stress is needed in the healing process, it is recommended that nurses use therapeutic communication techniques with bibliotherapy so that the child becomes cooperative with the nursing actions taken and the healing process goes well

\section{ACKNOWLEDGMENTS}

We would like to thank the Ministry of Research and Technology / National Research and Innovation Agency, Deputy for Strengthening Research and Development for the opportunity that has been given to us to obtain research grants for Beginner Lecturers for Research Implementation in 2020. and do not forget to thank the respondents and all parties, so that this research can be completed properly

\section{REFERENCES}

Adriana Dian, (2011). Tumbuh Kembang dan Terapi Bermain Anak. Jakarta: Salemba Medika

Agustina, Susanti, (2017). Biblioterapi Untuk Pengasuhan. Bandung: Noura Publishing Apriza, (2017). Jurnal Obsesi Pengaruh Biblioterapi Dengan Buku Cerita Bergambar Terhadap Tingkat Kecemasan Efek Hospitalisasi pada Anak Prasekolah. https://www.researchgate.net/publication. Diakses pada tanggal 20 November 2018, jam 13.00 WIB

Apriliawati, Anita, (2011). Pengaruh Biblioterapi Terhadap Tingkat Kecemasan Anak Usia Sekolah Yang Menjalani Hospitalisasi di Rumah Sakit Islam Jakarta. Tesis Program Magister Keperawatan Peminatan Keperawatan Anak Fakultas Ilmu Keperawatan Universitas Indonesia, Depok

Apriany, Dyna, (2013). Hubungan Antara Hospitalisasi Anak dengan Tingkat Kecemasan Orang Tua. http://jks.fikes.unsoad.ac.id/index.php/jks/ article/view/477. Diakses pada tanggal 20 November 2018, jam 13.40 WIB

Astarani, Kili, (2017). Hospitalisasi \& Terapi Bermain Anak. Prambon Nganjuk: Adjie Media Nusantara

Dewi, Arum, Purwanti, (2016). Efektivitas Biblioterapi dan Guided Imagery Terhadap Tingkat Kecemasan pada Anak Prasekolah yang Menjalani Hospitalisasi di RSUD Tugurejo

Semarang. http://ejournal.stikestelogorejo.ac.id/index.php/ilmukeperawatan/article/view/529.

Diakses pada tanggal 20 November 2018, jam 13.15 WIB

Hidayat, Dede, Rahmat, (2018). Konseling disekolah Pendekatan-pendekatan

Kontemporer. Jakarta: Prenada Media Group

Ismianto, (2018). Hubungan Sikap Perawat Dengan Stres Akibat Hospitalisasi pada Anak Usia Pra sekolah di RSU Pancaran Kasih GMIM Manado. https://ejournal.unsrat.ac.id

Jahja, Yudrik, (2015). Psikologi Perkembangan. Jakarta: Prenadamedia Group.

Muhith, Abdul \& Siyoto, Sandu, (2018). Aplikasi Komunikasi Terapeutik Nursing \& Health. Yogyakarta: Andi (Anggota IKAPI)

Nursalam, (2013). Metodologi Keperawatan. Jakarta: Salemba Medika 


\section{STRADA Jurnal Ilmiah Kesehatan}

DOI: $10.30994 /$ sjik.v9i2.412

ISSN: 2252-3847 (print); 2614-350X (online)

Vol.9 No.2 November 2020 Page.917-925

Nursalam, (2008). Pendidikan Dalam Keperawatan. Jakarta: Salemba Medika

Riyadi, Sujono \& Sukarmin, (2009). Asuhan Keperawatan pada Anak. Yogyakarta: Graha Ilmu

Suparyo, Yossy, (2010). Bagaimana Penerapan Biblioterapi. http://www. kombinasi.net/bagaimana-menerapkan-biblioterapi/. Diakses tanggal 09 Februari 2019, jam 10.00 WIB

Saputro, Heri, (2017). Anak Sakit Wajib Bermain di Rumah Sakit. Ponorogo: Forum Ilmiah kesehatan (FORIKES)

Suhron, Muhammad, (2017). Asuhan Keperawatan Jiwa Konsep Self Esteem. Jakarta: Mitra Wacana Media

Sulistyani, (2010). Biblioterapi. https://www.gogle.com/amp/s/sulistyanibkusd11. wordpress.com/2014/03/10/biblioterapi/amp. Diakses tanggal 09 Februari 2019, jam 10.20 WIB

Susilaningrum, Rekawati, (2013). Asuhan Keperawatan Bayi \& Anak. Jakarta: Salemba Medika

Wahyuni, Anggika, (2016). Tingkat Kecemasan pada Anak Prasekolah yang Mengalami Hospitalisasi Berhubungan Dengan Perubahan Pola Tidur di RSUD Karanganyar. $\quad$ https://www.jurnal.stikes.aisyiyah.ac.id/index. php/gaster/article/view/121. Diakses pada tanggal, 20 November 2018, jam 13.35 WIB 